\title{
Shelf Life of Azospirillum brasilense in Alginate Beads Enriched With Trehalose and Humic Acid
}

\author{
Sharlini Laís Zago ${ }^{1}$, Marise Fonseca dos Santos ${ }^{1}$, Daniela $\mathrm{Konrad}^{1}$, Adriana Fiorini ${ }^{1}$, Fábio Rogério Rosado ${ }^{1}$, \\ Robson Fernando Missio ${ }^{2} \&$ Eliane Cristina Gruszka Vendruscolo ${ }^{1}$ \\ ${ }^{1}$ Labiogen-Laboratory of Biochemistry and Genetics, Federal University of Paraná, Palotina, PR, Brazil \\ ${ }^{2}$ Department of Agronomy Sciences, Federal University of Paraná, Palotina, PR, Brazil \\ Correspondence: Eliane Cristina Gruszka Vendruscolo, Labiogen-Laboratory of Biochemistry and Genetics, \\ Federal University of Paraná, Setor Palotina, Rua Pioneiro, 2153, Palotina, PR, CEP 85950-000, Brazil. Tel: \\ 55-443-211-8577. E-mail: egvendru@gmail.com
}

Received: February 1, 2019

Accepted: March 5, 2019 Online Published: May 15, 2019

doi:10.5539/jas.v11n6p269

URL: https://doi.org/10.5539/jas.v11n6p269

\begin{abstract}
Since abiotic and biotic factors can compromise the survival of bacteria and their viability, encapsulation of cells in biodegradable gel matrices, a biological macromolecule, is one alternative to have their shelf life extended. Here, it was developed a gel-based formulation of the bioinoculant Azospirillum brasilense strain AbV5 and determined the effect of trehalose and humic acid supplementation in viability and survival of bacteria. For each $2 \mathrm{ml}$ of sodium alginate solution (3\%), $1 \mathrm{ml}$ of the inoculum was extruded in a solution containing sodium alginate complexed with calcium chloride, forming calcium alginate beads. Supplements were used in a ratio of 2:2:1. Treatments were peat; alginate; alginate + humic acid; alginate + trehalose $0.1 \mathrm{M}$; alginate + trehalose $1 \mathrm{M}$. Morphometric aspects, survival rate and viability were determined in 9 storage periods $(3,5,7,14,21,30,45,60$, 90 days). As results, beads were able to sustain the growth of $A$. brasilense for 90 days. Shelf life quality decreased in all treatments and peat remained the best carrier. Encapsulation, despite promoting the greatest losses in the survival of bacteria in the first days, ensured better cell viability. Trehalose in low concentrations $(0.1 \mathrm{M})$ improved cell viability during storage, optimizing plant inoculation.
\end{abstract}

Keywords: additives, encapsulation, inoculants, survival and viability

\section{Introduction}

World food production is based on the extensive use of chemical fertilizers, which not only pollute the environment but also are expensive due to their non-renewable sources like fossil fuels, used in their exploitation, transportation and application (Schoebitz, López, \& Roldán, 2013). Therefore, eco-friendly and economical alternatives have been increasingly demanded. Among some of these alternatives, plant-growth promoting bacteria (PGPB) are sustainable and low-cost biofertilizers, but need specific formulation when used in agronomical practices (Malusa \& Vassilev, 2014).

Biofertilizers as inoculants must have 3 fundamental characteristics: to promote bacterial growth; to keep the cells viable for a certain period of time and to release a minimum population of bacteria, which will certainly be associated to plants (Yoav Bashan et al., 2014; Shcherbakova et al., 2018). Microbial survival after soil inoculation depends on both abiotic and biotic factors. The population of the inoculated bacteria declines progressively over time, preventing the accumulation of a bacterial pool in the rhizosphere sufficient to promote beneficial effects (Yoav Bashan, 1998; Sivakumar, Parthasarthi, \& Lakshmipriya, 2014).

Nutritional conditions, humidity, temperature, and $\mathrm{pH}$ of soil solution are factors that compromise the survival of bacteria in the rhizosphere. In addition, the survival of the inoculated bacteria depends to a large extent on the availability of a specific niche in which competition for nutrients or substrates does not exist. It also depends on the resistance to predation and/or on the mutualistic coexistence with the native microflora, generally more adapted (Reetha, Kumaresan, \& John Milton, 2014; Schoebitz et al., 2013). Peat is the most common carrier used in the inoculant industry and it is widely recommended to several plant crops (Yoav Bashan et al., 2014). It has a large water adsorption capacity, promoting a favorable microenvironment to cell growth and maintenance 
(Kaljeet, Keyeo, \& Amir, 2011). However, it has as disadvantages little protection to the stresses caused by storage and environmental stresses caused to the bacteria after inoculation (Yoav Bashan, 1998).

Alternatives that aim the improvement of viability of bacteria and extension of shelf life are important for the emergence of a greater number of types of inoculants that combine with different bacterial species and methods (see review Berninger, Mitter, \& Preininger, 2016). One of the most successful, safe and effective methods to add bacteria to the soil is by encapsulation of cells in biodegradable gel matrices (Cassidy, Lee, \& Trevors, 1996; Vassilev et al., 2015). The hydrogel is formed by the interaction between sodium alginate and $\mathrm{Ca}^{+2}$ ions via the ionotropic gelation mechanism (Burey, Bhandari, Howes, \& Gidley, 2008). Alginate is a natural polymer composed of $\beta-(1 \rightarrow 4)$-linked D-mannuronic acid and $\alpha-(1 \rightarrow 4)$-linked L-guluronic acid, both produced by brown algae (Macrocystis pyrifera), as well as by bacteria (Pseudomonas sp and Azotobacter sp) (Hay, Rehman, Ghafoor, \& Rehm, 2010; Nehra \& Choudhary, 2015).

The addition of supplements in the encapsulation procedure could optimize the survival and release of bacteria from the inoculant. Humic acid of high molecular weight and colloidal appearance has been efficient in improving the survival of encapsulated microorganisms (Reetha et al., 2014; Young, Rekha, Lai, \& Arun, 2006). Trehalose, in turn, is a disaccharide that can be used as source of energy and as protector against dehydration. Trehalose can increase the viability of freeze-drying cells as $70 \%$ of them survived after drying (Leslie, Israeli, Lighthart, L. Crowe, \& J. Crowe, 1995), compared to other adjuvants (Pereira, Oliver, Bliss, L. Crowe, \& J. Crowe, 2002). Nevertheless, the effect of trehalose and humic acid on the survival and viability of alginate encapsulated cells, in a short period of storage, remains unknown.

The objective of this paper was to develop the gel-based formulation of the bioinoculant Azospirillum brasilense strain AbV5 and to determine if trehalose and humic acid can effectively enhance the viability and survival of bacteria along storage period.

\section{Method}

\subsection{Encapsulation and Gel-based Bioinoculant Formulations}

A. brasilense strain AbV5 was maintained by continuous cultivations in NFb Lactate solid medium at $28{ }^{\circ} \mathrm{C}$. The pre-inoculum was prepared by transferring a bacteria colony into a $5 \mathrm{~mL}$ of $\mathrm{NFb}$ Lactate medium at $32{ }^{\circ} \mathrm{C}$ in a shaker incubator. After $24 \mathrm{~h}, 1 \mathrm{~mL}$ of pre-inoculum was transferred to $50 \mathrm{~mL}$ of NFb-Lactate medium, constituting the inoculum, which had been maintained under the same conditions as described before. The log phase of cell growth was measured by turbidimetry at $600 \mathrm{~nm}$.

The encapsulation of $A$. brasilense cells in beads was performed according to the protocol proposed by Reetha et al. (2014) with modifications. The proportion was 2:1 in order to obtain beads (for each $2 \mathrm{~mL}$ of sodium alginate solution (3\%), $1 \mathrm{~mL}$ of the bacterial suspension was added). The ratio was 2:2:1 when the supplement was used. To avoid fungal and other bacterial contamination, Maxim'sTM $(0.01 \% \mathrm{v} / \mathrm{v})$ and nalidixic acid $\left(20 \mu \mathrm{g} \mathrm{mL} \mathrm{L}^{-1}\right)$ were added.

Before extrusion, the mixture was kept under gentle stirring for $30 \mathrm{~min}$ in sterile conditions for complete homogenization. The mixture was extruded through a Pasteur pipette into a beaker containing sterile $0.1 \mathrm{M}$ $\mathrm{CaCl}_{2}$ solution, under gently stirring at room temperature. The macrobeads were maintained in $\mathrm{CaCl}_{2}$ solution for $2 \mathrm{~h}$ so that solid beads of homogeneous size could be formed. The $\mathrm{CaCl}_{2}$ solution was drained and the beads washed twice with sterile water. After washing, the beads were incubated in NFb-Lactate liquid medium for $24 \mathrm{~h}$ in a shaker at $120 \mathrm{rpm}$ and $32{ }^{\circ} \mathrm{C}$ to allow bacteria to multiply inside them. Afterwards, the beads were washed again twice with autoclaved distilled water, collected and left under air stream for $30 \mathrm{~min}$. Aliquots of approximately $7 \mathrm{~g}$ of beads each were packed into $3 \mathrm{~mm}$-thick plastic bags. In total, 30 packets of beads were made from each treatment.

Innocuous peat $\left(\mathrm{Nitro} 1000^{\mathrm{TM}}\right.$ ) served as control, where 30 packets of $7 \mathrm{~g}$ were inoculated with $1 \mathrm{~mL}$ of peptone solution containing A. brasilense $\left(10^{9} \mathrm{CFU} \mathrm{mL}^{-1}\right)$. All packages or aliquots containing the different formulations were stored in a dry place in the dark and at a temperature of $21 \pm 2{ }^{\circ} \mathrm{C}$.

The experimental design was entirely randomized with 5 different formulations tested (peat; alginate; alginate + humic acid $(0.8 \%)$; alginate + trehalose $0.1 \mathrm{M}$; alginate + trehalose $1 \mathrm{M})$. For each treatment the survival and viability $\left.(\mathrm{CFU} \mathrm{mL})^{-1}\right)$ of $A$. brasilense cells were evaluated at 9 different storage periods $(3,5,7,14,21,30,45$, 60, 90 days of storage) in triplicate, totalizing 27 packets for these evaluations until the last day. The 90 days were chosen because is the maximum period that usually farmers maintain inoculants stocked before sowing.

Beads were diametrically measured $(\mathrm{mm})$ with a graduated ruler and weighted $(\mathrm{mg})$ in an analytical balance in triplicate after the encapsulation of the bacterial cells. 


\subsection{Electronic Scan Microscopy (SEM)}

External surfaces of the spheres were scanned using the Scanning Electron Microscope (SEM) technique (FEI Quanta 440). The bead-shaped samples were subjected to fixation with $0.2 \mathrm{M}$ sodium cacodylate buffer ( $\mathrm{pH}=$ 7.2), followed by dehydration with increasing concentrations of ethanol (50\% for $15 \mathrm{~min}, 60 \%$ for $15 \mathrm{~min}, 70 \%$ for $15 \mathrm{~min}, 80 \%$ for $15 \mathrm{~min}, 90 \%$ for $15 \mathrm{~min}$ and $100 \%$ for $15 \mathrm{~min}$ ). After dehydration, the supernatant was discarded and the beads received $1.5 \mathrm{~mL}$ of cool acetone. Samples were placed on the sample set, which contained a double-sided carbon tape, and were subsequently dried and metallized with a thin layer of gold on the surface so that a photo could capture.

\subsection{Evaluation of the Survival of Viable Cells or Microbial Counting}

Three packages containing aliquots of beads from each treatment in different periods of storage were analyzed. From each aliquot, 10 beads were taken and dissolved in a falcon tube containing $10 \mathrm{~mL}$ of potassium phosphate buffer $(0.25 \mathrm{M}, \mathrm{pH} 6.8 \pm 0.1)$. The tubes were kept in a BOD incubator for $16-24 \mathrm{~h}$ at $30 \pm 2{ }^{\circ} \mathrm{C}$. After this period, and for complete solubilization of beads, tubes were shaken for $1 \mathrm{~min}$ in a vortex. Serial dilutions $(10 \times)$ and plating were performed following the protocol of Romeiro (2001) that is by counting bacterial colonies that were visible on nutrient agar plates after $24 \mathrm{~h}$ of inoculation.

\subsection{Efficiency of Encapsulation}

It was proposed to measure the encapsulation efficiency by the ratio between the log-UFC mL ${ }^{-1}$ obtained at the inoculation day (day 0) and the log after encapsulation (1st day).

\subsection{Viability and Release of A. brasilense After Inoculation of Wheat Seeds}

In vitro assay was performed with 40 wheat seeds (cv CD 104) in each treatment. Seeds were washed according to a protocol suggested by Neiverth et al. (2014). Subsequently, they were placed in agar-water medium at $30 \pm 2$ ${ }^{\circ} \mathrm{C}$ and kept there for 3 days for complete germination. At the 4 th day, the inoculum was prepared with 20 beads diluted in $3 \mathrm{~mL}$ of potassium phosphate solution $(0.25 \mathrm{M}, \mathrm{pH} 6.8 \pm 0.1)$. Around 20 pre-germinated wheat seeds were immersed in the inoculum for $3 \mathrm{~h}$ at $30 \pm 2{ }^{\circ} \mathrm{C}$. Test tubes containing $25 \mathrm{~mL}$ of distilled water and $5 \mathrm{~cm}$ of polypropylene pellets were prepared to support the inoculated seeds. Each pre-germinated and inoculated seed was transferred to the test tubes, randomly arranged under a photoperiod of $16 \mathrm{~h} / 8 \mathrm{~h}$ of light/dark, respectively, at temperature of $25 \pm 2{ }^{\circ} \mathrm{C}$, where the seeds stayed for 7 days.

\subsection{Counting of Epiphytic Bacterial Population}

The epiphytic bacterial population was evaluated after 7 days of inoculation. Three plants had their roots washed 3 times with distilled and autoclaved water, placed in tubes containing $\mathrm{NaCl}$ solution $(0.9 \%)$ and sonicated for 20 s. Serial dilutions $(10 \times)$ and plating followed the protocol of Romeiro (2001). The plates were kept at $30 \pm 2{ }^{\circ} \mathrm{C}$ for $48 \mathrm{~h}$. The evaluation was done in triplicate. The colony-forming units (CFU) obtained were counted using a stereoscopic magnifying glass (Quimis).

\subsection{Molecular identification of A. brasilense}

The epiphytic bacteria were detected using PCR amplification of a 648 bp region belonging to A. brasilense $16 \mathrm{~S}$ rDNA region, with the primers Azo16SF (5'-GCGGTAATACGAAGGGGGCK-3') and Azo16SR (5'TTGTCACCGGCAGTTCCACCAG-3') (Shime-Hattori et al, 2011). Bacterial samples were collected randomly at the encapsulation day $\left(1^{\text {st }}\right.$ day) and from the epiphytic sampling, taking into consideration the period of storage $(3,5,7,14,21,30,45,60,90$ days of storage).

One single bacterial colony, obtained after growth in NFb-L medium, was transferred to a PCR microtube and resuspended in $20 \mu \mathrm{L}$ of ultrapure water. Cells were lysed through heating at $96{ }^{\circ} \mathrm{C}$ for $6 \mathrm{~min}$. The supernatant was separated from the cell lysate by brief centrifugation. PCR was performed in a volume of $20 \mu \mathrm{L}$ using $2 \mu \mathrm{L}$ of DNA, $1 \times$ PCR Buffer, $1.5 \mathrm{mM} \mathrm{MgCl} 2,0.4 \mathrm{mM}$ dNTP mix, 1 unit of Taq DNA Polymerase (4G Research and Development), and $0.2 \mu \mathrm{M}$ of each primer. The reaction was conducted in a Bioer Life Express model MJ96 thermal cycler, with cycling conditions as follows: initial denaturation at $94{ }^{\circ} \mathrm{C}$ for $3 \mathrm{~min}$, followed by 25 cycles of $94{ }^{\circ} \mathrm{C}$ for $30 \mathrm{~s}, 58^{\circ} \mathrm{C}$ for $1 \mathrm{~min}, 72^{\circ} \mathrm{C}$ for $1 \mathrm{~min}$, with final extension of $72{ }^{\circ} \mathrm{C}$ for $5 \mathrm{~min}$. PCR products were visualized in agarose gels $1.5 \%$ stained by $0.5 \mu \mathrm{g} \mathrm{mL}^{-1}$ ethidium bromide in $1 \times$ TBE Buffer $(90 \mathrm{mM}$ Tris-base; $90 \mathrm{mM}$ boric acid; $2 \mathrm{mM}$ EDTA pH 8.0) and photo documented with the equipment Loccus Biotechnology model L.PIX. The standard molecular weight of $100 \mathrm{bp}$ (NorgenTM) was used. 


\subsection{Statistical Analysis}

The colony forming units (CFU) data were transformed into log (base 10) for comparison using the Microsoft Office Excel. Data were submitted to analysis of variance (ANOVA) and the means were compared by the Tukey test $(\mathrm{p}<0.05)$, by the statistical program GENES (Cruz 2006). The data were expressed with a mean \pm SD $(\mathrm{n}=$ $3)$.

Individual analyses of polynomial regression were carried out in the statistical program GENES to evaluate the outcomes of the treatments, assuming time of storage and survival and viability (within epiphytic population) as variables. Statistical significance of $\beta 1$ and $\beta 2$ coefficients were estimated by the F-test $(p \leq 0.05)$.

\section{Results}

\subsection{Morphometric Aspects of the Beads Produced}

The encapsulated beads remained with the same morphological appearance throughout the evaluation period, preserving the color and shape until the $90^{\text {th }}$ day (Figures 1A-1D).
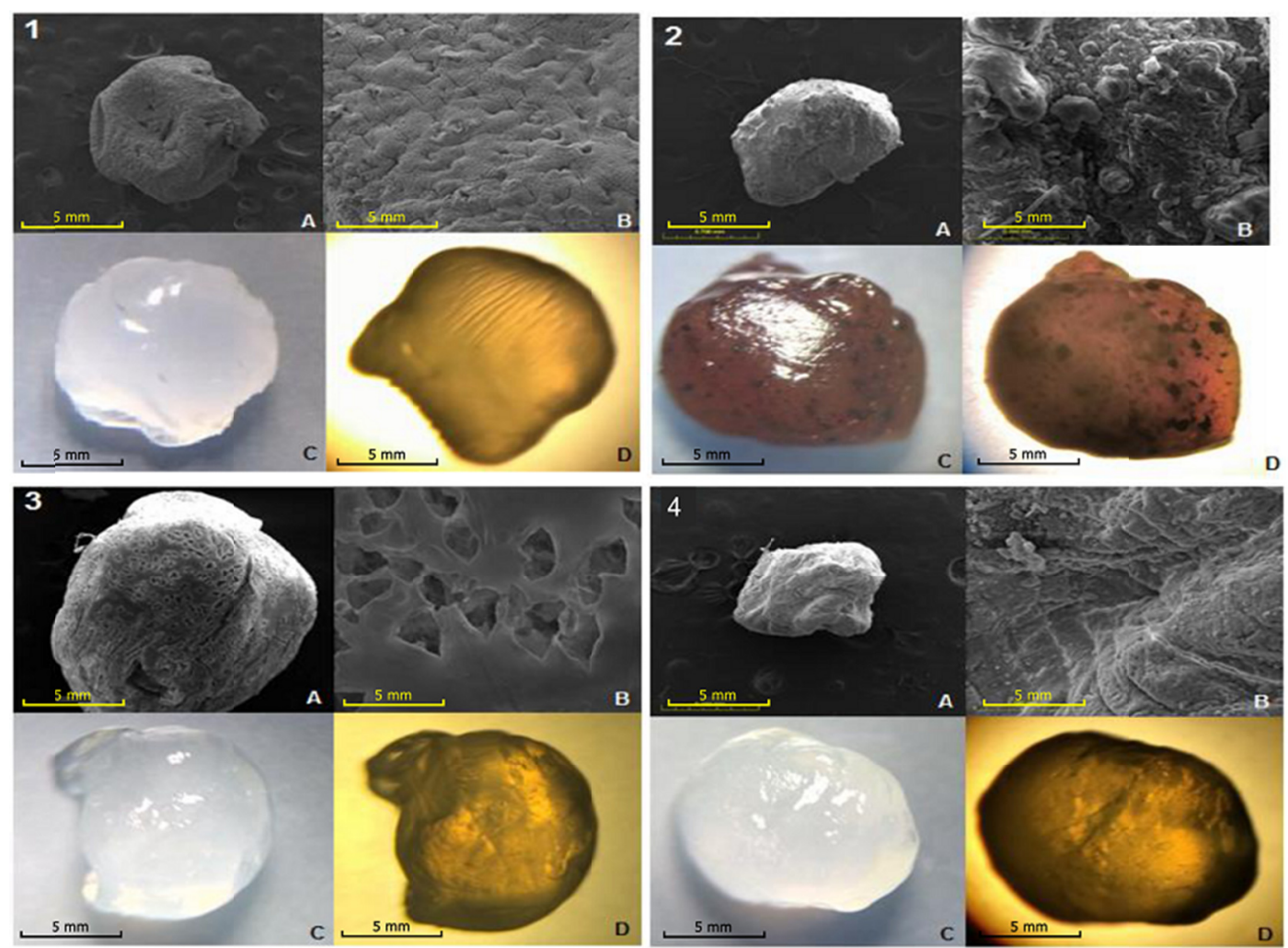

Figure 1. Morphological aspects of beads. 1. Alginate; 2. Alginate + Humic Acid 0.8\%; 3. Alginate + Trehalose $0.1 \mathrm{M} ; 4$. Alginate + Trehalose 1M. A: External surface, increase of $120 \times$; B. Internal surface, increase of 120×;

C. Contre-jour picture; D. Incident light. Bar-5 mm

The morphometric data obtained at the 1st day after encapsulation are shown in Table 1 . The beads had spherical shape, with their diameter measured individually. The mean size ranged from 3.3 to $4.3 \mathrm{~mm}$, which confirms that the protocol used was efficient to generate beads of uniform size.

Beads weighted from 17 to $38 \mathrm{mg}$. Weight decreased when trehalose was added and increased in humic acid enriched alginate beads (Table 1).

The efficiency of encapsulation ranged from $40-61 \%$. Trehalose (1M) decreased $15-20 \%$ the encapsulation efficiency, compared to control (alginate) (Table 1).

\subsection{Survival of A. brasilense in Beads of the Different Formulations}

All treatments in this experiment were planned to start with the inoculum containing a population of $10^{9} \mathrm{CFU}$ $\mathrm{mL}^{-1}$. However, at the first day (day 0 ) the concentration of the bacterial population observed was approximately 
$10^{12} \mathrm{CFU} \mathrm{mL} \mathrm{mL}^{-1}$ in all treatments (Table 1). This increase may be explained by the protocol implemented, which recommends that the solution should be gently shaken for extra $30 \mathrm{~min}$ after the mixture components are added. Reetha et al. (2014) observed an initial population increase of about 1000 times.

Table 1. Morphometric and encapsulation efficiency analyses

\begin{tabular}{llllll}
\hline Treatments $^{\mathrm{a}}$ & Weight $(\mathrm{mg})$ & Diameter $(\mathrm{mm})$ & E.E. $(\%)^{\mathrm{b}}$ & $\begin{array}{l}\text { Survival }\left(\mathrm{CFU} \mathrm{mL} \mathrm{mL}^{-1}\right) \\
\left(10^{12}\right) /(\log )-\text { Initial }\end{array}$ & $\begin{array}{l}\text { Viability }\left(\mathrm{CFU} \mathrm{mL}^{-1}\right) \\
\left(10^{12}\right) /(\log ) \text {-Initial }\end{array}$ \\
\hline Peat & - & - & - & $6.43 / 12.80$ & $1.07 / 8.95$ \\
Alginate & $38 \pm 3.78 \mathrm{a}$ & $4.30 \pm 0.57 \mathrm{a}$ & 59 & $7.86 / 12.90$ & $7.86 / 9.85$ \\
Alginate + Humic Acid & $32 \pm 0.57 \mathrm{ab}$ & $3.70 \pm 0.57 \mathrm{a}$ & 56 & $7.86 / 12.90$ & $7.86 / 9.85$ \\
Alginate + Trehalose 0.1M & $17 \pm 1.52 \mathrm{c}$ & $3.30 \pm 0.59 \mathrm{a}$ & 61 & $7.10 / 14.70$ & $7.86 / 9.85$ \\
Alginate + Trehalose 1M & $30 \pm 2.64 \mathrm{~b}$ & $4.00 \pm 0.85 \mathrm{a}$ & 40 & $6.43 / 12.80$ & $1.07 / 8.95$ \\
\hline
\end{tabular}

Note. ${ }^{\mathrm{a}}$ Treatments followed by different letter differ significantly by Tukey test $(p<0.05)$. ${ }^{\mathrm{b}} \mathrm{E} . \mathrm{E}$ (efficiency of encapsulation).

The treatment with peat also generated an initial population of $10^{12} \mathrm{CFU} \mathrm{mL}^{-1}$, demonstrating a continuous bacteria growth with this carrier as well. Nevertheless, a small decrease was observed at the 1st until the last day of evaluation (Figure $2 \mathrm{~A}$ ), except for the $14^{\text {th }}$ day, when the $\mathrm{CFU} \mathrm{m \textrm {m } ^ { - 1 }}$ was around $12 \%$ higher in relation to the week before. The bacteria population at the end $\left(90^{\text {th }}\right.$ day $)$ was $36 \%$ lower than the initial one $\left(2.8 \times 10^{9} \mathrm{CFU}\right.$ $\mathrm{mL}^{-1}$ ).

In the experiment with alginate, viable bacterial cells were observed in all storage periods, which indicates that encapsulation did not prevent cell growth (Figure 2A). At the $90^{\text {th }}$ day, the population of bacteria in alginate beads was $12 \%$ lower compared to the first day $\left(5 \times 10^{7} \mathrm{CFU} \mathrm{mL}^{-1}\right)$.

A

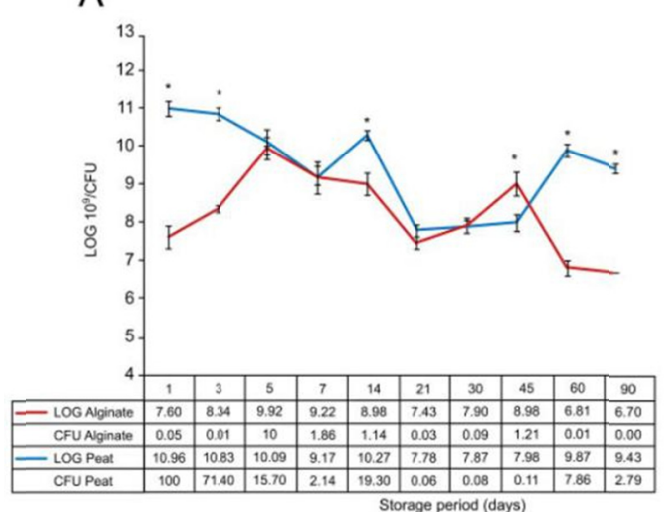

Storage period (days)

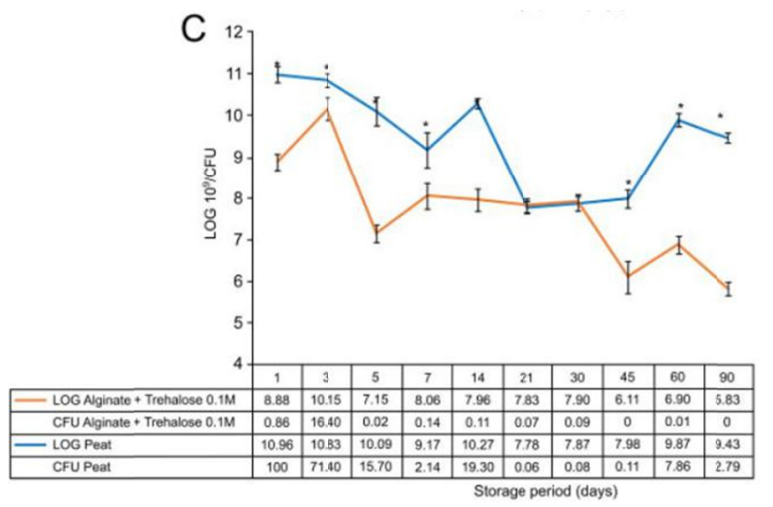

B
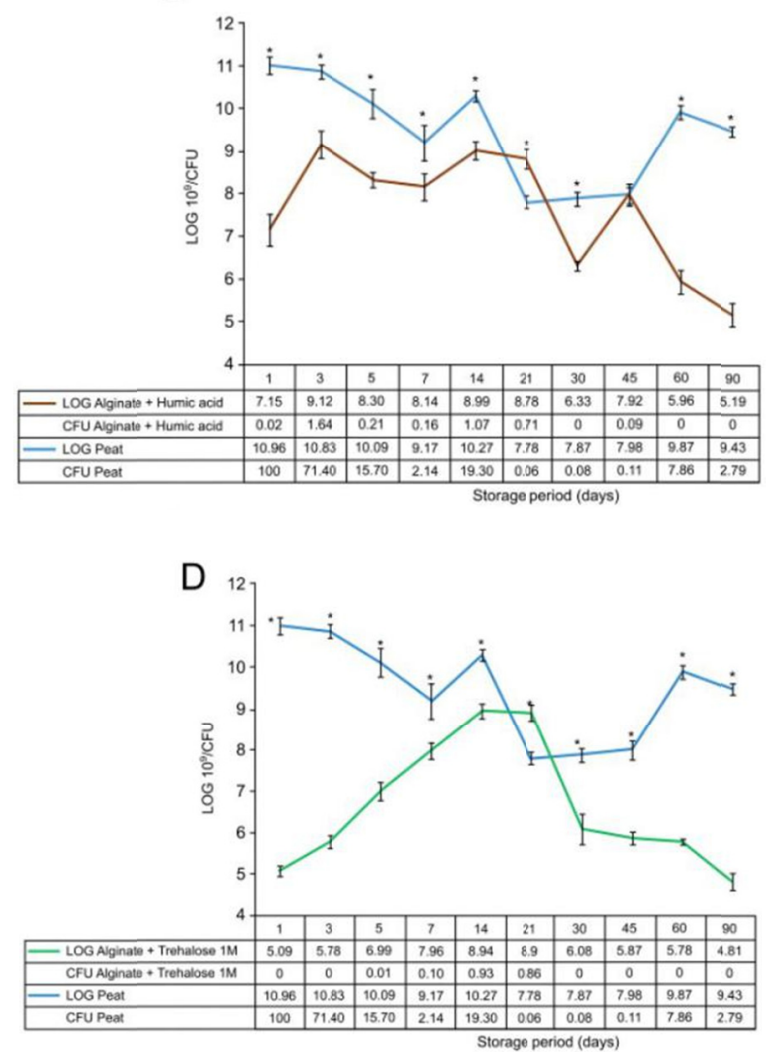

Figure 2. Survival of A. brasilense on different carriers matter during storage period. A. Alginate; B. Alginate + Humic Acid; C. Alginate + Trehalose 0.1M; D. Alginate + Trehalose 1M. * Treatments differ by Tukey test P > $5 \%$. Peat was used as control. CFU is given as multiple of $10^{9} \mathrm{~mL}^{-1}$ 
Humic acid induced outcome similar to the one observed with alginate. After the first day, the microbial population found in the cells encapsulated with humic acid was 1.53 times lower than in peat (Figure 2B). After 3 days of storage, microbial population increased $27 \%$. At the end of the observation, CFU was lower than $10^{9}$, corresponding to $55 \%$ of the bacterial population in peat.

Trehalose was tested in 2 different concentrations $(0.1$ and $1 \mathrm{M})$, which produced distinct effects over the encapsulated microbiota (Figures $2 \mathrm{C}-2 \mathrm{D})$. At the lowest concentration $(0.1 \mathrm{M})$ growth acceleration was observed right after the 1st day of storage, probably because of a bigger energy source in addition to the growth phase of the encapsulated bacteria (Figure 2C). A higher concentration of carbon in the encapsulated medium when trehalose was added was confirmed by EDS (Energy-dispersive X-ray spectroscopy) (data not shown). After 72 $\mathrm{h}$ of storage, there was a sharp fall (41\%) of the CFU compared to peat on the same evaluation day. Trehalose $(0.1 \mathrm{M})$ supply was over after the 3rd day of storage. After 3 months of storage, bacterial population was $38 \%$ lower than the one found in peat.

The highest concentration of trehalose $(1 \mathrm{M})$ (Figure 2D) promoted a significant tendency to increase survival of bacteria until the $21^{\text {st }}$ day of storage (14\% higher). This improvement is explained by the high concentration of $\mathrm{C}$ in this disaccharide, which is used by bacteria as source of energy. However, after 21 days, as this rate declined, so did the survival of bacteria. After 3 months of storage, the formulation had its CFU diminished to almost half of peat's bacterial population.

\subsection{Viability of A. brasilense During the Storage Period}

The viability of $A$. brasilense after the encapsulation process and storage was evaluated through an in vitro test in which the bacteria that truly associated with the wheat seedlings — epiphytic bacteria — were quantified.

In all treatments, encapsulation demonstrated a beneficial effect on the epiphytic population (Figures 3A-3D). Peat presented a population ranging from $10^{7}$ to $10^{9} \mathrm{CFU} \mathrm{mL}^{-1}$ over the 90 days of storage. This population had a decrease of $22 \%$ on the $7^{\text {th }}$ day after the encapsulation. At the last day of evaluation, the population adhered to the wheat roots was $10^{9} \mathrm{CFU} \mathrm{mL}^{-1}$ (Figure $3 \mathrm{~A}$ ).
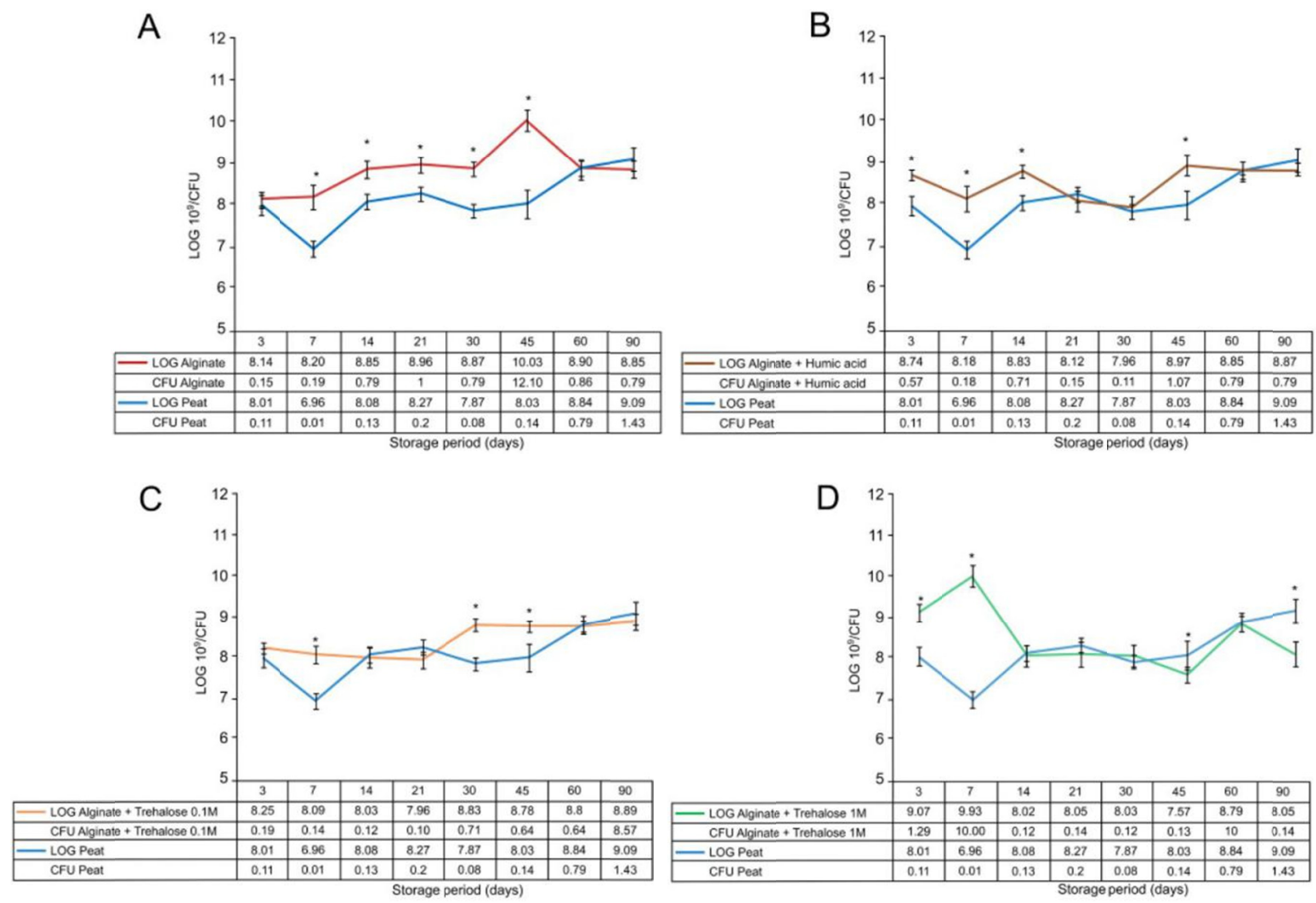

Figure 3. Viability of A. brasilense on different carriers matters during storage period. A. Alginate; B. Alginate + Humic Acid; C. Alginate + Trehalose 0.1M; D. Alginate + Trehalose $1 \mathrm{M} .{ }^{*}$ significative $(\mathrm{P}>5 \%)$. Peat was used as control. CFU is given as multiple of $10^{9} \mathrm{~mL}^{-1}$ 
Encapsulation in calcium alginate matrix without supplements presented an epiphytic population superior to peat in practically all the periods of evaluation. This population was similar to peat at the $3^{\text {rd }}$ day after storage. On the $45^{\text {th }}$ day, the population adhered to the wheat roots was $25 \%$ higher than the one found in peat, which indicates advantages in the use of encapsulation. On the other hand, the epiphytic population was $2.7 \%$ lower than peat on the last day of evaluation.

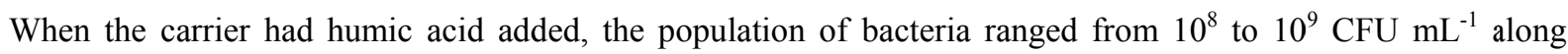
storage period (Figure 3B). Although the population adhered to roots increased $9 \%$ after 14 days of storage, this rate, after 3 months, was $2.5 \%$ lower than the population in peat.

The supplementation with trehalose at $0.1 \mathrm{M}$ during encapsulation was more effective until the $45^{\text {th }}$ day (except the 21 days of storage) in relation to peat. However, epiphytic population in beads decreased at the last day ( $90^{\text {th }}$ day) of evaluation (Figure 3C).

Trehalose at the highest concentration $(1 \mathrm{M})$ demonstrated to have a potent effect on bacteria viability until the $7^{\text {th }}$ day of storage. After this day, the rate of CFU mL ${ }^{-1}$ decreased to levels similar to peat. On the $90^{\text {th }}$ day of storage, the population adhered to the wheat roots was $12 \%$ lower than peat (Figure 3D).

Molecular analyses of the samples randomly collected from the epiphytic bacteria attached to seedlings roots confirmed the presence of $A$. brasilense as deriving from the inoculum used (Figure 4).

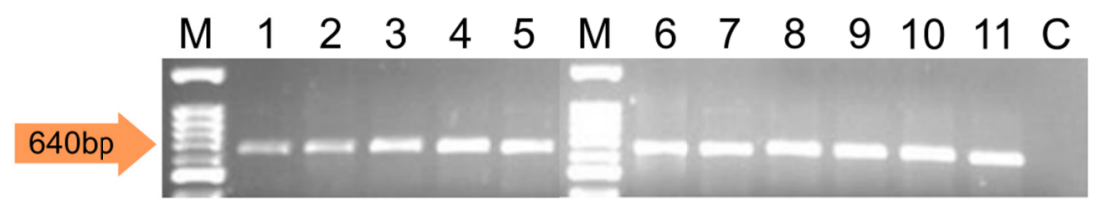

Figure 4. PCR analyses confirming A.brasilense presence in samples collected in different periods of storage. Bands 1 to 5 correspond to samples collected at the $1^{\text {st }}$ day after encapsulation; M. Molecular Ladder 100pb; 1 . Peat; 2. Alginate; 3. Alginate + Humic acid; 4. Alginate + Trehalose $0,1 \mathrm{M} ; 5$. Alginato + Trehalose 1M; Bands 6 to 11 were from bacteria epiphytically adhered to wheat roots: 7. Peat (7 days); 8 . Alginate (14 days); 9 . Alginate + Humic acid (21 days); 10. Alginate+ Trehalose 0,1M (30 days); 11. Alginate + Trehalose 1M (90 days); C. Negative Control

The data were submitted to individual and joint analyses of regression, using viability and survival as variables in the functions of all evaluated treatments in order to verify if any variable is significant within treatments and to obtain a performance model (Table 2 and Figure 5). Analyses confirmed peat as the best option to support bacterial survival during 90 days of storage. Simple linear regression equations showed that treatments with alginate, alginate + humic acid and alginate + trehalose $0.1 \mathrm{M}$ caused significant decrease in the survival rate of $A$. brasilense (Figure 5A). 
A

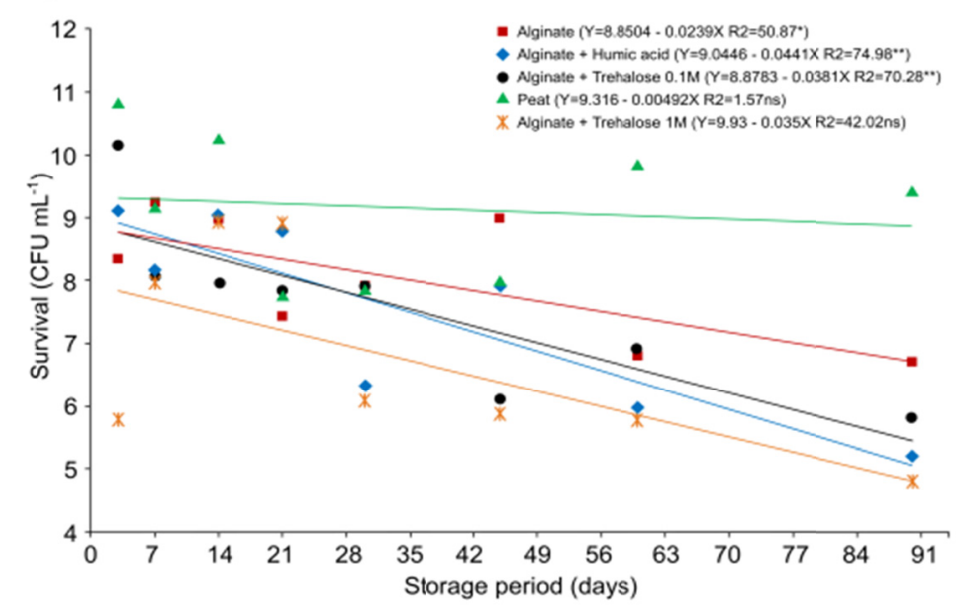

B

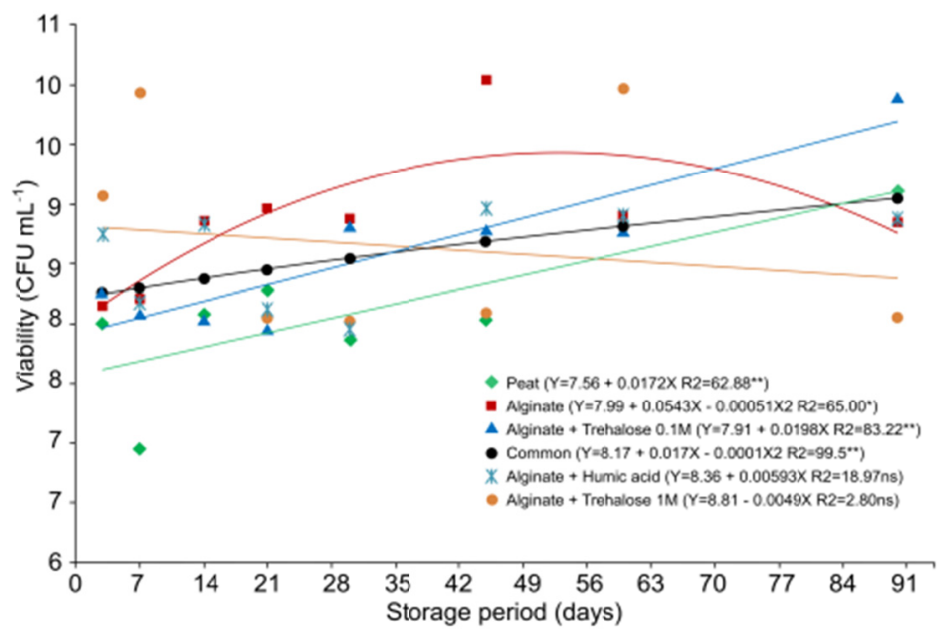

Figure 5. Projection of individual and joint regression for survival (A) and viability (B) of bacterial cells as a function of evaluated treatments. * and **indicate significant difference at $P<0.05$ and $P<0.01$, respectively. ns indicate no significant

On the other hand, when only alginate was used as carrier (p-value 0.0497 ), the results showed a tendency to decrease viability after 60 days of storage (Figure 5B). The treatments with alginate + humic acid and alginate + trehalose $1 \mathrm{M}$ did not present significant equations of $A$. brasilense viability.

Table 2. Joint regression analysis for viability and survival variables as a function of all evaluated treatments

\begin{tabular}{|c|c|c|c|c|c|c|}
\hline \multirow{2}{*}{ Treatments } & \multicolumn{3}{|l|}{ Survival (CFU mL mL $\left.^{-1}\right)$} & \multicolumn{3}{|c|}{ Viability $\left(\mathrm{CFU} \mathrm{mL}^{-1}\right)$} \\
\hline & Regression Model & $\mathbf{R}^{2}(\%)$ & p-value & $\begin{array}{l}\text { Regression Model } \\
\end{array}$ & $R^{2}(\%)$ & p-value \\
\hline \multirow[t]{2}{*}{ Peat } & $Y=9.31615385-0.00492308 X$ & 1.57 & 0.7631 & $\mathrm{Y}=7.56+0.0172 \mathrm{X}$ & 62.88 & 0.0188 \\
\hline & $Y=10.3240404-0.0858 X+0.0009 X^{2}$ & 36.55 & 0.1562 & $Y=7.59+0.0152 X+0.000022 X^{2}$ & 62.94 & 0.9247 \\
\hline \multirow[t]{2}{*}{ Alginate } & $\mathrm{Y}=8.85-0.02386 \mathrm{X}^{2}$ & 50.87 & $0.0461 *$ & $\mathrm{Y}=8.56+0.0084 \mathrm{X}$ & 18.90 & 0.2819 \\
\hline & $\mathrm{Y}=8.77-0.0178 \mathrm{X}-0.00007 \mathrm{X}^{2}$ & 51.14 & 0.8688 & $\mathrm{Y}=7.99+0.0543 \mathrm{X}-0.00051 \mathrm{X}^{2}$ & 65.00 & $0.0497 *$ \\
\hline \multirow[t]{2}{*}{ Alginate + Humic Acid } & $\mathrm{Y}=9.04-0.0441 \mathrm{X}$ & 74.98 & $0.0057 *$ & $\mathrm{Y}=8.36+0.00593 \mathrm{X}$ & 18.97 & 0.2810 \\
\hline & $Y=9.11-0.0499 X+0.000064 X^{2}$ & 75.08 & 0.8846 & $Y=8.44-0.00055 X+0.000072 X^{2}$ & 20.83 & 0.7421 \\
\hline \multirow[t]{2}{*}{ Alginate + Trehalose $0.1 \mathrm{M}$} & $\mathrm{Y}=8.88-0.0381 \mathrm{X}$ & 70.28 & $0.0095 *$ & $Y=7.91+0.0198 X$ & 83.22 & $0.0018^{*}$ \\
\hline & $\mathrm{Y}=9.42-0.0819 \mathrm{X}+0.00049 \mathrm{X}^{2}$ & 77.91 & 0.2454 & $\mathrm{Y}=8.078+0.0063 \mathrm{X}+0.00015 \mathrm{X}^{2}$ & 86.41 & 0.3290 \\
\hline \multirow[t]{2}{*}{ Alginate + Trehalose $1 \mathrm{M}$} & $Y=7.93-0.035 X$ & 42.02 & 0.0805 & $\mathrm{Y}=8.81-0.0049 \mathrm{X}$ & 2.80 & 0.6921 \\
\hline & $Y=7.65-0.0122 X-0.00025 X^{2}$ & 43.48 & 0.7315 & $\mathrm{Y}=8.97-0.0177 \mathrm{X}+0.00014 \mathrm{X}^{2}$ & 4.35 & 0.7819 \\
\hline Joint regression & No ajust & & & $\mathrm{Y}=8.21+0.011 \mathrm{X}-0.000025 \mathrm{X}^{2}$ & 99.52 & 0.0000 \\
\hline
\end{tabular}

Note. *Significative at $5 \%$. 


\section{Discussion}

To promote bacteria survival and viability is the main challenge for the inoculation technology, once shelf life is influenced by several parameters: bacterial species, culture medium, physiological condition of the microorganisms, dehydration process, storage temperature and water concentration in the inoculum (Schoebitz et al., 2013; Sivasakthivelan \& Saranraj, 2013).

In order to bacteria function as promoters of plant growth, they must reach the root, survive for a certain period of time to associate with plants, and compete with other bacteria in the rhizosphere. Therefore, formulations should provide protection to bacteria longevity (Vassilev et al., 2015).

In relation to the morphological appearance, some beads exhibited striations, agreeing with other authors who observed grooves in the surface of the encapsulated beads (Berninger et al., 2016). The humic acid beads presented dark spots, probably caused by deposition of the humic acid or other impurities. The wrinkled aspect, originated from invaginations, could explain the weight gain in some treatments. This result corroborates with those obtained by other authors who observed by microphotography a wrinkled and grooved area (Bashan, Carriers, \& Bashan, 1986; Sivakumar et al., 2014). The formulation of alginate enriched with humic acid presented higher porosity, similar to what Young et al. (2006) found. On the other hand, the treatment using trehalose formed beads of smoother appearance, without invaginations, which would explain their lower weights.

(Ivanova, Teunou, \& Poncelet, 2005) reported another protocol in which the beads size ranged from 1 to $5 \mathrm{~mm}$, and observed that by increasing the spheres size, bacteria survival enhanced 36\%. Reetha et al. (2014) obtained encapsulated particles of smaller size $(1.3$ to $3.2 \mathrm{~mm}$ ) and lower weight ( 0.5 to $10.3 \mathrm{mg}$ ) compared to our data, which is explained by the type of pipetting instrument used during the extrusion of the inoculum.

In the literature, different concentrations of microorganisms in inoculant formulations ( $\mathrm{CFU} \mathrm{mL}$ ) are reported: $10^{9}$ (Reetha et al., 2014); $10^{10}$ (Young et al., 2006); $10^{6}$ (Marcelino, Milani, Mali, Santos, \& Oliveira, 2016); $10^{3}$ (O'Callaghan, 2016). Encapsulation demands high population density during inoculation in order to ensure the minimum population desired. Shah-Smith and Burns (Shah-Smith \& Burns, 1996) reported a population of $6 \times$ $10^{7} \mathrm{CFU} \mathrm{mL} \mathrm{m}^{-1}$ after inoculation of seeds using a cell density of $2 \times 10^{10}$ of Pseudomonas putida.

Study by Amiet-Charpentier, Gadille, Digat, and Benoit (1998) showed that alginate matrix was not toxic or incompatible with Pseudomonas cells. However, in all treatments the $\mathrm{CFU} \mathrm{mL} \mathrm{L}^{-1}$ decreased significantly $24 \mathrm{~h}$ after encapsulation. This evidence suggests that extrusion caused a harmful or stressing effect on the bacterial population encapsulated (Figures 2A-2D). After 48h of encapsulation, alginate motivated a sharp decline in the CFU of about $44 \%$ in relation to the $1^{\text {st }}$ day (Table 1) and 35\% compared to peat during the same period. This result corroborates the research by Ivanova et al. (2002) who observed greater decrease in the initial phase, after extrusion (7 days). Bashan et al. (2002) observed that the microencapsulation process affects the survival of bacteria due to the cross-linking of the alginate-calcium complex with the cell membrane of the bacteria, killing many of them.

Among all formulations, peat demonstrated the best capacity in maintaining bacterial survival throughout storage period. According to Kaljeet et al. (2011), peat was the only carrier that maintained $10^{7} \mathrm{CFU} \mathrm{mL}{ }^{-1}$ of rhizobia for up to 8 weeks of storage. Our results are distinct from those obtained by Reetha et al. (2014), who observed a reduction in the microbial population of around $57 \%$ in only 6 days of evaluation, but it shifted after 90 days, when the population increased to $10 \times 10^{9} \mathrm{CFU} \mathrm{mL}^{-1}$.

Young et al., (2006) had also tested alginate supplemented with humic acid, but did not detect loss of microbiota $\left(2 \times 10^{8} \mathrm{CFU} \mathrm{g} \mathrm{g}^{-1}\right.$ of beads) after $24 \mathrm{~h}$ of encapsulation or even after 5 months of storage. The great difference between their data and ours can be partially explained by the instrument they used during the extrusion, a 26-gauge needle, smaller than one used in this work, thus forming much smaller beads (1 to $2 \mathrm{~mm}$ ). Smaller beads would be preferable for their survival than the larger ones.

In a similar protocol, but with a concentration of $2.5 \%$ of sodium alginate, humic acid promoted a smaller reduction in the CFU mL ${ }^{-1}$ of $A$. lipoferum (Reetha et al., 2014). The authors reported that the beneficial effect occurred because humic acid increased porosity, enhancing oxygenation and access to nutrients, facilitating cellular metabolism within the beads.

O'Callaghan (2016) reported that the greatest benefits of supplements in the encapsulation formulations are to provide the bacteria better life conditions to withstand stresses as well as to improve cell vigor. However, data did not show improvement of CFU during periods longer than 3 weeks of storage compared to peat. 
The best performance of peat regarding cell survival and viability after 90 days of storage can be explained by its high moisture holding capacity, since there may have been loss of water during encapsulation (Kaljeet et al., 2011). The calcium alginate matrix, on the other hand, is rich in water (97-98\%), meaning that it would fail to provide cell protection, stated Bashan et al. (2002). Schoebitz et al. (2013) demonstrated that the addition of starch to alginate reduced the water concentration to $65 \%$ and improved significantly bacterial survival. Another factor that could explain the success of peat as carrier is that it provides better oxygenation. The inconvenience, however, is the great rates of contamination: without nalidixic acid and fungicide, it was not possible to carry out the evaluations using peat as control.

Results of viability ( $\mathrm{CFU} \mathrm{mL} \mathrm{m}^{-1}$ ) polynomial regression analyses showed that all treatments can be represented by the common regression equation $\left(\mathrm{Y}=8.21+0.011 \mathrm{X}-0.000025 \mathrm{X}^{2}\right.$, Figure $\left.5 \mathrm{~B}\right)$. The treatments with peat (p-value 0.0188$)$ and alginate + trehalose $0.1 \mathrm{M}$ (p-value 0.0018$)$ showed linear increases in viability, and the combination of alginate + trehalose $0.1 \mathrm{M}$ presented the highest mean value of viability, suggesting a positive effect of this disaccharide in helping encapsulated cells become vigorous until reaching the rhizosphere and associate with plants. The results obtained with trehalose at low concentrations (Figures 2C and 5B) can open up the potential for new formulations using some PGPB strains that strive to survive, even without encapsulation.

Medium and higher concentrations of trehalose in inoculants formulations should be tested to check possible improvements in bacterial survival. The positive results of increase in cell survival and viability, found in the formulations with trehalose mainly right after encapsulation, confirm the protective effect of trehalose on proteins and components of the cell membrane at the initial phase of bacteria growing inside the beads (Leslie et al., 1995).

\section{Conclusions}

The gel-based formulation of Azospirillum brasilense developed with sodium alginate (3\%) was competent to produce beads of uniform size that sustained bacteria growth and viability along 90 days of storage. Peat was the best carrier to support bacteria survival. Encapsulation in a gel matrix provided higher cell viability, mainly when low concentration $(0.1 \mathrm{M})$ of trehalose was added. These findings can optimize plant inoculation.

\section{Acknowledgements}

Special thanks to Nitro1000 Inoculantes Biológicos (Cascavel, PR, Brazil) for providing some of the materials used in this experiment. The authors would like to thank the Academic Publishing Advisory Center (Centro de Assessoria de Publicação Acadêmica, CAPA—www.capa.ufpr.br) of the Federal University of Paraná for assistance with English language editing.

\section{References}

Amiet-Charpentier, C., Gadille, P., Digat, B., \& Benoit, J. P. (1998). Microencapsulation of rhizobacteria by spray-drying: Formulation and survival studies. Journal of Microencapsulation, 15(5), 639-659. https://doi.org/10.3109/02652049809008247

Bashan, Y. (1998). Inoculants of plant growth-promoting bacteria for use in agriculture. Biotechnology Advances, 16(4), 729-770. https://doi.org/10.1016/S0734-9750(98)00003-2

Bashan, Y., Carriers, S. I., \& Bashan, Y. (1986). Alginate beads as synthetic inoculant carriers for slow release of bacteria that affect plant growth. Applied and Environmental Microbiology, 51(5), 1089-1098.

Bashan, Y., De-Bashan, L. E., Prabhu, S. R., Hernandez, J.-P. P., Bashan, L. E., Prabhu, S. R., \& Hernandez, J.-P. P. (2014). Advances in plant growth-promoting bacterial inoculant technology: Formulations and practical perspectives (1998-2013). Plant and Soil, 378(1-2), 1-33. https://doi.org/10.1007/s11104-013-1956-x

Berninger, T., Mitter, B., \& Preininger, C. (2016). The smaller, the better? The size effect of alginate beads carrying plant growth-promoting bacteria for seed coating. Journal of Microencapsulation, 33(2), 127-136. https://doi.org/10.3109/02652048.2015.1134690

Burey, P., Bhandari, B. R., Howes, T., \& Gidley, M. J. (2008). Hydrocolloid Gel Particles: Formation, Characterization, and Application. Critical Reviews in Food Science and Nutrition, 48(5), 361-377. https://doi.org/10.1080/10408390701347801

Cassidy, M. B., Lee, H., \& Trevors, J. T. (1996). Environmental applications of immobilized microbial cells: A review. Journal of Industrial Microbiology, 16(2), 79-101. https://doi.org/10.1007/BF01570068

Hay, I. D., Rehman, Z. U., Ghafoor, A., \& Rehm, B. H. A. (2010). Bacterial biosynthesis of alginates. Journal of Chemical Technology and Biotechnology, 85(6), 752-759. https://doi.org/10.1002/jctb.2372 
Ivanova, E., Chipeva, V., Ivanova, I., Dousset, X., \& Poncelet, D. (2002). Encapsulation of Lactic Acid Bacteria in Calcium Alginate Beads for Bacteriocin Production. Journal of Culture Collections, 3, 53-58.

Ivanova, E., Teunou, E., \& Poncelet, D. (2005). Alginate based macrocapsules as inoculants carriers for production of nitrogen biofertilizers. In B. Gruev, M. Nikolova, \& A. Donev (Eds.), Balkan Scientific Conference of Biology in Plovdiv from 19th till 21st of may 2005 (pp. 90-108). Plovid.

Kaljeet, S., Keyeo, F., \& Amir, H. G. (2011). Influence of carrier materials and storage temperature on survivability of rhizobial inoculant. Asian Journal of Plant Sciences. https://doi.org/10.3923/ajps.2011. 331.337

Leslie, S. B., Israeli, E., Lighthart, B., Crowe, J. H., \& Crowe, L. M. (1995). Trehalose and sucrose protect both membranes and proteins in intact bacteria during drying. Applied and Environmental Microbiology, 61(10), 3592-3597.

Malusa, E., \& Vassilev, N. (2014). A contribution to set a legal framework for biofertilisers. Applied Microbiology and Biotechnology, 98(15), 6599-6607. https://doi.org/10.1007/s00253-014-5828-y

Marcelino, P. R., Milani, K. M. L., Mali, S., Santos, O. J. A. P., \& Oliveira, A. L. M. (2016). Formulations of polymeric biodegradable low-cost foam by melt extrusion to deliver plant growth-promoting bacteria in agricultural systems. Applied Microbiology and Biotechnology, 100(16), 7323-7338. https://doi.org/ 10.1007/s00253-016-7566-9

Nehra, V., \& Choudhary, M. (2015). A review on plant growth promoting rhizobacteria acting as bioinoculants and their biological approach towards the production of sustainable agriculture. Journal of Applied and Natural Science, 7(1), 540-556. https://doi.org/10.31018/jans.v7i1.642

Neiverth, A., Delai, S., Garcia, D. M., Saatkamp, K., de Souza, E. M., Pedrosa, F. de O., ... da Costa, A. C. T. (2014). Performance of different wheat genotypes inoculated with the plant growth promoting bacterium Herbaspirillum seropedicae. European Journal of Soil Biology, 64, 1-5. https://doi.org/10.1016/j.ejsobi. 2014.07.001

O'Callaghan, M. (2016). Microbial inoculation of seed for improved crop performance: issues and opportunities. Applied Microbiology and Biotechnology, 100(13), 5729-5746. https://doi.org/10.1007/s00253-016-7590-9

Pereira, P. A. A., Oliver, A., Bliss, F. A., Crowe, L., \& Crowe, J. (2002). Preservation of rhizobia by lyophilization with trehalose. Pesquisa Agropecuária Brasileira, 37(6), 831-839. https://doi.org/10.1590/ S0100-204X2002000600012

Reetha, D., Kumaresan, G., \& John Milton, D. (2014). Studies to improve the shelf life of Azospirillum lipoferum immobilized in alginate beads. International Journal of Recent Scientific Research, 5(12), 2178-2182. https://doi.org/10.24327/IJRSR

Romeiro, R. S. (2001). Métodos em bacteriologia de plantas. Viçosa, MG: UFV.

Schoebitz, M., López, M. D., \& Roldán, A. (2013). Bioencapsulation of microbial inoculants for better soil-plant fertilization. A review. Agronomy for Sustainable Development, 33(4), 751-765. https://doi.org/10.1007/ s13593-013-0142-0

Shah-Smith, D. A., \& Burns, R. G. (1996). Biological control of damping-off of sugar beet by Pseudomonas putida applied to seed pellets. Plant Pathology, 45, 572-582. https://doi.org/10.1046/j.1365-3059.1996. d01-156.x

Shcherbakova, E. N., Shcherbakov, A. V, Rots, P. Y., Gonchar, L. N., Mulina, S. A., Yahina, L. M., ... Chebotar, V. K. (2018). Inoculation technology for legumes based on alginate encapsulation. Agronomy Research, $16(5), 2156-2168$.

Shime-Hattori, A.,Kobayashi,S.,Ikeda,S.,Asano,R.,Shime,H., \& Shinano,T. (2011).A rapid and simple method for identifying isolates of genus Azospirillum within populations of rhizosphere bacteria. Journal of Applied Microbiology, 111(4),915-924. https://doi.org/101111/j.1365-2672.2011.05115.x

Sivakumar, P. K., Parthasarthi, R., \& Lakshmipriya, V. P. (2014). Encapsulation of plant growth promoting inoculant in bacterial alginate beads enriched with humic acid. Int. J. Curr. Microbiol.App. Sci., 3(6), 415-422.

Sivasakthivelan, P., \& Saranraj, P. (2013). Azospirillum and its Formulations: A Review. International Journal of 
Microbiological Research, 4(3), 275-287. https://doi.org/10.5829/idosi.ijmr.2013.4.3.825

Vassilev, N., Vassileva, M., Lopez, A., Martos, V., Reyes, A., Maksimovic, I., ... Malusà, E. (2015). Unexploited potential of some biotechnological techniques for biofertilizer production and formulation. Applied Microbiology and Biotechnology, 99(12), 4983-4996. https://doi.org/10.1007/s00253-015-6656-4

Young, C.-C., Rekha, P. D., Lai, W.-A., \& Arun, A. B. (2006). Encapsulation of plant growth-promoting bacteria in alginate beads enriched with humic acid. Biotechnology and Bioengineering, 95(1), 76-83. https://doi.org/10.1002/bit.20957

\section{Copyrights}

Copyright for this article is retained by the author(s), with first publication rights granted to the journal.

This is an open-access article distributed under the terms and conditions of the Creative Commons Attribution license (http://creativecommons.org/licenses/by/4.0/). 